\title{
Dynamic Regulation of NGFI-A (zif268, egr1) Gene Expression in the Striatum
}

\author{
R. Moratalla, ${ }^{1}$ H. A. Robertson, ${ }^{2}$ and A. M. Graybiel ${ }^{1}$ \\ 'Department of Brain and Cognitive Sciences, Massachusetts Institute of Technology, Cambridge, Massachusetts 02139 \\ and 'Department of Pharmacology, Faculty of Medicine, Dalhousie University, Halifax, Nova Scotia B3H 4H7, Canada
}

The expression of immediate-early genes of the fos/jun leucine zipper family can be regulated in striatal neurons by stimuli affecting the dopaminergic nigrostriatal system. The regulatory effects are gene specific, region specific, and striatal compartment specific. In the experiments reported here, we have explored the possibility that dopaminergic stimulation might also affect striatal expression of NGFI-A, a member of the zinc finger family of immediate-early genes. We treated healthy adult rats with amphetamine or cocaine and monitored the acute response of striatal neurons by in sifu hybridization with oligonucleotide probes for NGFI-A mRNA. Both drugs evoked rapid, anatomically patterned increases in NGFI-A mRNA expression in the dorsal striatum (caudoputamen) and in the ventral striatum (nucleus accumbens, olfactory tubercle). The main response to each drug was in medium-sized neurons, known to be the projection neurons of the striatum. At every dose of amphetamine eliciting a response, the increased NGFI-A mRNA expression was preferentially concentrated in striosomes of the rostral caudoputamen, whereas cocaine at each dose given induced expression of NGFI-A mRNA in both striosomes and matrix at these striatal levels. The two indirect agonists evoked NGFI-A expression in both striatal compartments farther caudally, especially in the central and medial caudoputamen. Activation by both drugs was blocked by pretreatment with the D1-selective dopamine receptor antagonist SCH23390. These patterns of NGFI-A activation are remarkably similar to those found for Fos-like immunoreactivity following acute amphetamine and cocaine treatments, suggesting that coordinate activation of members of at least two immediate-early gene families occurs in the striatum following catecholaminergic stimulation. Such patterns of induction strongly support the view that the genomic responsiveness of the striosome and of the matrix compartments of the rostral striatum are distinct at the level of earlyresponse gene expression. These findings raise the interesting possibility that some of the well-known effects of

\footnotetext{
Received July 24, 1991; revised Dec. 26, 1991; accepted Feb. 7, 1992.

It is a particular pleasure to thank Ms. Amelia Rosales for her help with the in situ hybridization, Ms. Celia Shneider for her help with word processing, and Mr. H. F. Hall for his work on the photography. This work was supported by the United Parkinson Foundation, NIII Javits Award R01NS25529, the IIuman Frontier Science Program, and a grant from the Seaver Institute.

Correspondence should be addressed to Dr. Ann M. Graybiel, Department of Brain and Cognitive Sciences, Massachusetts Institute of Technology, E25-618, 77 Massachusetts Avenue, Cambridge, MA 02139.

Copyright (C) 1992 Society for Neuroscience $0270-6474 / 92 / 122609-14 \$ 05.00 / 0$
}

dopaminergic stimulation on neuropeptide and neurotransmitter expression in the striatum may reflect particular combinatorial patterns of immediate-early gene activation.

Striosomes and matrix are neurochemically distinct macroscopic compartments characteristic of the striatum of many mammalian forms including humans. In the past dozen years, a very large number of neurotransmitter-related differences between these two compartments have been identified in anatomical studies, and striosomes and matrix have been shown to have different patterns of input-output connections and different developmental histories (see Graybiel, 1990, for review). This evidence and the results of push-pull cannula experiments testing dopamine release in the striatum (Gauchy et al., 1987; Kemel et al., 1989) provide indirect support for the idea that the two compartments represent functionally distinct subsystems in the striatum, striosomes being especially linked to certain limbic regions and matrix to certain sensorimotor regions of the forebrain (Donoghue and Herkenham, 1986; Ragsdale and Graybiel, 1988; Gerfen, 1989; Graybiel, 1990). Direct evidence for functional differences between striosomes and matrix is still lacking, however, and in particular, physiological evidence on this question has been difficult to obtain because of the low levels of firing of most striatal neurons in acute in vivo and in vitro preparations (DeLong and Georgopoulos, 1981; Misgeld et al., 1984; Nisenbaum et al., 1988).

Because of these difficulties, we recently attempted to monitor functional activation of neurons in the two striatal compartments by eliciting activation of immediate-early genes in the striatum by dopamine agonist stimulation (Graybiel et al., 1990; Moratalla et al., 1990). We took advantage of earlier findings that a variety of stimuli can induce expression of immediateearly gene mRNAs and gene products in system-specific patterns in the brain and spinal cord (Dragunow and Robertson, 1987; Hunt et al., 1987; Morgan et al., 1987; Sagar et al., 1988; Robertson et al., 1989; for review, see Sheng and Greenberg, 1990). Our strategy was to treat rats with drugs that are known to act on the nigrostriatal system, and to test anatomically for acute changes in expression of Fos-like protein in the striatum. We chose as drugs amphetamine and cocaine, indirect dopamine agonists that increase dopamine levels in the striatum by releasing catecholamines (the main effect of amphetamine) or binding to the dopamine transporter (the main effect of cocaine). These drugs induced strikingly different anatomical patterns of Fos-like immunoreactivity in the striosome and matrix compartments of the rostral caudoputamen. Amphetamine activated expression of Fos-like immunoreactivity that was most in- 
tense in the striosomal compartment, whereas cocaine induced apparently equivalent expression of Fos-like protein in striosomes and matrix, especially centrally and medially. The expression of Fos-like protein stimulated by each drug was blocked by the D1-like dopamine receptor-preferring antagonist $\mathrm{SCH} 23390$, indicating that the induction was receptor mediated. The induction by cocaine was abolished by pretreatment with reserpine, but the induction by amphetamine was reserpine resistent. These findings raised the possibility that the striosome and matrix systems of the rostral caudoputamen may be functionally activated through stimuli affecting different intracellular signaling systems related to biogenic amine receptors. Young et al. (1991) and Cole et al. (1990) have also dcmonstrated apparent D1 dopamine receptor selectivity of striatal c-fos induction by cocaine and amphetamine.

In the experiments reported here, we set out to test the generality of this compartment-selective pattern of acute genomic response by determining the effects of dopamine agonist treatments on striatal expression of NGFI-A (zif/268, egr 1, and krox 24), a member of the zinc finger family of immediate-early genes (Lau and Nathans, 1987; Milbrandt, 1987; Sukhatme et al., 1987, 1988; Christy et al., 1988; Lemaire et al., 1988; Waters et al., 1990). NGFI-A is highly responsive to neural stimulation and, in the hippocampal model of long-term potentiation (LTP), is more consistently induced by the high-frequency stimulation required for LTP there than are c-fos and other leucine zipper genes so far examined (Saffen et al., 1988; Cole et al., 1989; Wisden et al., 1990). We document here that amphetamine and cocaine rapidly increase the expression of NGFI-A mRNA in the caudoputamen and ventral striatum, and demonstrate that in the rostral caudoputamen the effects are striosome selective in response to amphetamine but not in response to cocaine over a large range of drug doses. Compartmental selectivity in the genomic response of striatal neurons to psychomotor stimulants thus holds for members of at least two families of immediateearly genes whose gene products have different DNA binding motifs and may act in different combinatorial patterns in response to different sets of intracellular signals.

\section{Materials and Methods}

All experiments were carried out on adult male Sprague-Dawley rats $(230-350 \mathrm{gm}) \mathrm{kept}$ under a $12 \mathrm{hr}$ light $/ 12 \mathrm{hr}$ dark cycle, with free access to food and water. On the day of the experiment, animals were brought to a quiet (low-stress) room, and drugs or saline were administered after at least $4 \mathrm{hr}$ of light cycle. Drugs were dissolved in saline and were delivered by intraperitoneal injections at the following doses: $d$-amphetamine sulfate (Sigma), $0.5 \mathrm{mg} / \mathrm{kg}(n=2), 2 \mathrm{mg} / \mathrm{kg}(n=3), 5 \mathrm{mg} /$ $\mathrm{kg}(n=3), 10 \mathrm{mg} / \mathrm{kg}(n=3)$, or $15 \mathrm{mg} / \mathrm{kg}(n=4)$; cocaine hydrochloride (Sigma), $5 \mathrm{mg} / \mathrm{kg}(n=3), 10 \mathrm{mg} / \mathrm{kg}(n=3), 25 \mathrm{mg} / \mathrm{kg}(n=4)$, or 50 $\mathrm{mg} / \mathrm{kg}(n=4) ; \mathrm{SCH} 23390$ (Schering-Plough), $0.5 \mathrm{mg} / \mathrm{kg}$ given $30 \mathrm{~min}$ before $5 \mathrm{mg} / \mathrm{kg}$ amphetamine $(n=4)$ or $25 \mathrm{mg} / \mathrm{kg}$ cocaine $(n=3)$. The doses of amphetamine and cocaine are expressed as their respective salts. After treatment, animals were observed for behavioral effects. Both drugs increased locomotor activity and induced stereotyped behavior in a dose-dependent fashion, with incrcases in head movement, sniffing, and rearing at higher doses. The effects of cocaine were evident 5-10 min after administration, and those of amphetamine at 15-20 min or even later. SCH23390 completely blocked the behavioral effects of amphetamine and cocaine.

Tissue preparation. One hour following the last drug treatment, the rats were decapitated, and their brains were rapidly removed and placed in powdered dry ice until frozen. Transverse sections were cut at 10$15 \mu \mathrm{m}$ on a cryostat, thaw mounted onto gelatin-coated slides, air dried, and stored at $-70^{\circ} \mathrm{C}$ until use.

Probe labeling. A 45 base oligonucleotide probe complementary to amino acids $2-16$ coded by $N G F I-A$ (zif/268) protein was used. Its sequence was 5'-CCG-TTG-CTC-AGC-AGC-ATC-ATC-TCC-TCCAGT-TTG-GGG-TAG-TTG-TCC-3' (Bio-synthesis, Denton, TX). The probe was labeled at the $3^{\prime}$ end with ${ }^{35}$ S-dATP (Du Pont/NEN) and terminal deoxynucleotidyl transferase (International Biotechnologies Incorporated) in a cobalt-containing buffer, and was purified in a NENsorb column (Du Pont/NEN) or Nunctrap push column (Stratagene), yielding a final radiolabeling of $0.4-1.2 \times 10^{6} \mathrm{cpm} / \mu \mathrm{l}$. For in situ hybridization controls, an oligonucleotide complementary to the antisense probe cited above was prepared according to the same protocol.

In situ hybridization. Selected sets of sections were fixed at room temperature for $5 \mathrm{~min}$ in $4 \%$ paraformaldehyde with $10 \mathrm{mM}$ phosphatebuffered saline (PBS), pH 7.4, and were then rinsed in PBS three times for $5 \mathrm{~min}$ each; placed in double-strength $(2 \times)$ saline-sodium citrate (SSC) buffer $(0.15 \mathrm{M} \mathrm{NaCl}, 15 \mathrm{~mm}$ sodium citrate) for $10 \mathrm{~min}$; dehydrated by sequential immersion in $50 \%, 70 \%, 95 \%$, and $100 \%$ ethanols $(3 \mathrm{~min}$ each); delipidated in chloroform for $10 \mathrm{~min}$; and dried under a cool stream of air. Sections were hybridized overnight at $37^{\circ} \mathrm{C}$ in a humid chamber with $1 \times 10^{6} \mathrm{cpm}$ of labeled oligonucleotide per $100 \mu \mathrm{l}$ of the hybridization buffer containing 50\% deionized formamide, $4 \times$ SSC, $1 \times$ Denhardt's solution $(0.02 \%$ bovine serum albumin, $0.02 \%$ ficoll, $0.02 \%$ polyvinylpyrrolidone), $500 \mu \mathrm{g} / \mathrm{ml}$ salmon sperm DNA, $250 \mu \mathrm{g} / \mathrm{ml}$ yeast tRNA, $10 \% \mathrm{w} / \mathrm{v}$ dextran sulfate, $100 \mathrm{~mm}$ dithiothreitol. After incubation, slides were rinsed twicc in $2 \times$ SSC and washed at room temperature, unless otherwise indicated, as follows: $1 \mathrm{hr}$ in $2 \times$ SSC, $1 \mathrm{hr}$ in $1 \times \mathrm{SSC}, 30 \mathrm{~min}$ in $0.5 \times \mathrm{SSC}, 30 \mathrm{~min}$ in $0.5 \times \mathrm{SSC}$ at $37^{\circ} \mathrm{C}, 30 \mathrm{~min}$ in $0.2 \times \mathrm{SSC}, 30 \mathrm{~min}$ in $0.1 \times \mathrm{SSC}$, and distilled water for $10 \mathrm{sec}$. All solutions contained $1 \%$ sodium thiosulfate and were continuously shaken. Once dried, sections were apposed to Hyperfilm $\beta \max$ (Amersham) for 3-8 weeks. After the films were developed, selected slides were dipped in NTB2 photographic emulsion (Kodak) applied at a 1:1 ratio with $0.1 \%$ Dreft detergent in $\mathrm{dH}_{2} \mathrm{O}$, dried, and stored at $4^{\circ} \mathrm{C}$ for $6-8$ weeks in light-tight boxes containing desiccant. After development, sections were stained for Nissl substance with cresylecht violet.

Opiate receptor autoradiography. Frozen sections adjacent to those chosen for in situ hybridization were brought to room temperature, preincubated for $5 \mathrm{~min}$ at $4^{\circ} \mathrm{C}$ in $50 \mathrm{mM}$ Tris- $\mathrm{HCl}$ buffer in $100 \mu \mathrm{M}$ $\mathrm{NaCl}$, and incubated for $60 \mathrm{~min}$ at $4^{\circ} \mathrm{C}$ in the same buffer containing $2.5 \mathrm{nM}{ }^{3} \mathrm{H}$-naloxone (Du Pont $/ \mathrm{NEN} ; 30.5 \mathrm{Ci} / \mathrm{mmol}$ ). After incubation, sections were washed three times in $50 \mathrm{~mm}$ PBS for $20 \mathrm{sec}$ at $4^{\circ} \mathrm{C}$, briefly rinsed in distilled water, dried, and apposed to tritium-sensitive film (LKB Ultrofilm) for 6 weeks. Nonspecific binding was determined by the addition of unlabeled naloxone, $10^{-6} \mathrm{M}$ (Sigma), to the incubation solution.

\section{Results}

Dose-dependent increases in NGFI- $A$ mRNA expression occur following acute amphetamine treatment

Treatment with amphetamine produced a dose-dependent increase in NGFI-A mRNA expression in the striatum, both in its dorsal part, the caudoputamen, and in its ventral part (including the nucleus accumbens and the olfactory tubercle) (Fig. $1 A-D)$. Low doses of amphetamine $(0.5 \mathrm{mg} / \mathrm{kg})$ did not produce a detectable increase in $N G F I-\mathrm{A}$ in the striatum. The hybridization signal in these brains was similar to that in brains from control rats treated with saline (see Fig. 7C). There was considerable signal in the cerebral cortex and strong signal in the piriform cortex. NGFI-A mRNA transcripts were also detectable in the striatum, but at much lower levels (cf Schlingensiepen et al., 1991). This control level of hybridization signal appeared to be homogeneously distributed within the caudoputamen and nucleus accumbens; there was slightly more signal in the olfactory tubercle than elsewhere in the striatum. Only one rat out of the three treated with $2 \mathrm{mg} / \mathrm{kg}$ exhibited a weak incrcasc in the hybridization signal in the striatum. At $5 \mathrm{mg} / \mathrm{kg}$, amphetamine always induced a strong and reliable increase in NGFI-A mRNA expression, as it did at higher doses.

In the rostral caudoputamen (Figs. $1 A-D, 2 A$ ), the in situ radiolabeling induced by amphetamine at each dose level had a highly heterogeneous distribution in which small $(\sim 100-300$ 

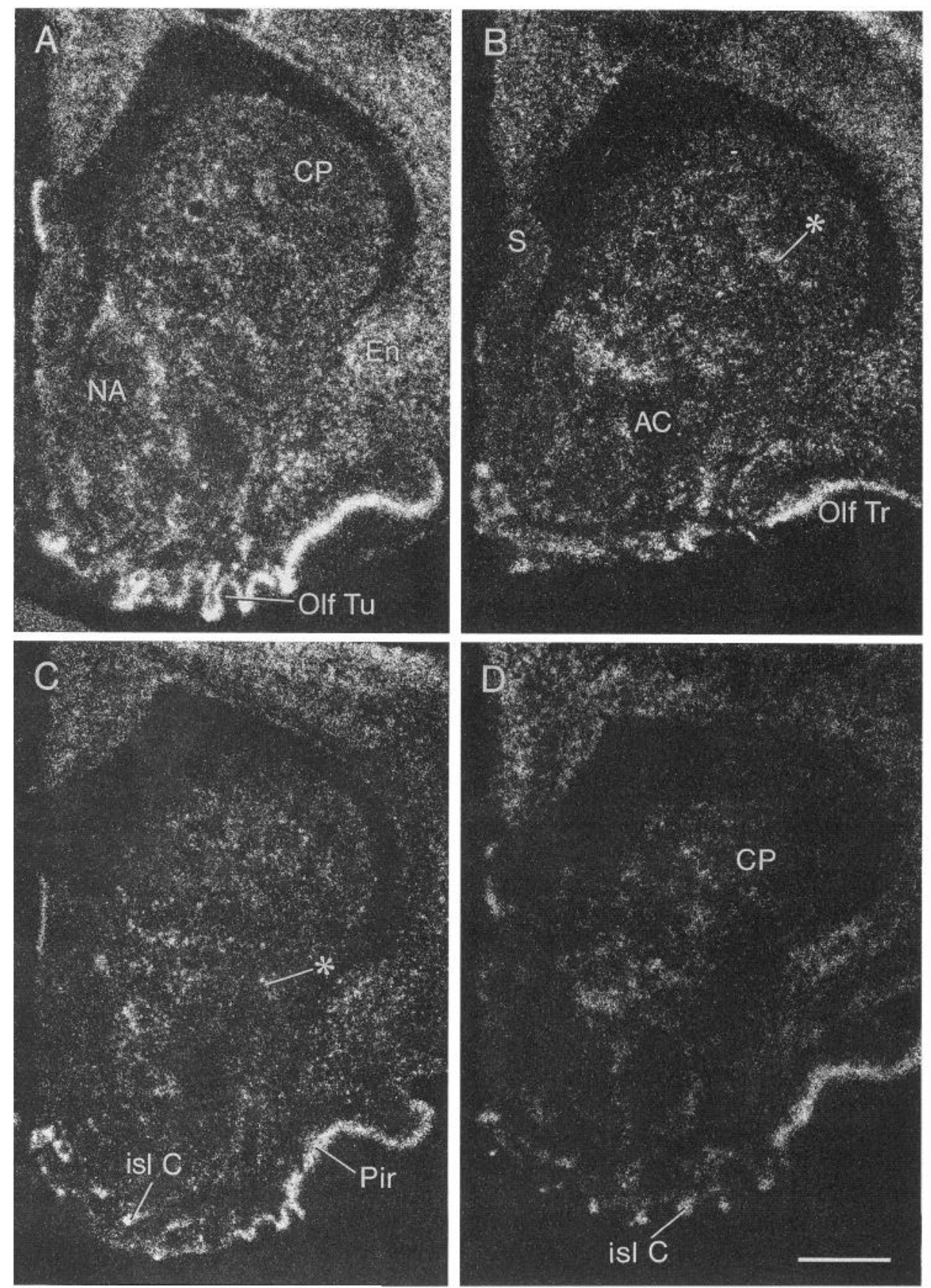

Figure 1. In situ autoradiograms of approximately matched striatal levels from adult rats, illustrating the highly heterogeneous pattern of increase in NGFI-A mRNA expression induced by amphetamine in the rostral caudoputamen at each of four different drug concentrations: $15 \mathrm{mg} / \mathrm{kg}(A), 10 \mathrm{mg} /$ $\mathrm{kg}(B), 5 \mathrm{mg} / \mathrm{kg}(C)$, and $2 \mathrm{mg} / \mathrm{kg}(D)$. Asterisks in $B$ and $C$ indicate examples of patches of heightened labeling. Compare with Figure 2. Survival times for all animals were $1 \mathrm{hr} . A C$, anterior commissure; $C P$, caudoputamen; isl $C$, island of Calleja; $E n$, endopiriform nucleus; $N A$, nucleus accumbens septi; Olf $T r$, olfactory tract; Olf $T u$, olfactory tubercle; Pir, piriform cortex; $S$, septum. Scale bar, $1 \mathrm{~mm}$. $\mu \mathrm{m}$ wide) patches of heightened labeling appeared scattered through the nucleus. This was true at each dose level eliciting a detectable response, including not only the lowest $(2.0 \mathrm{mg} / \mathrm{kg}$, Fig. $1 D)$ but also the highest $(15 \mathrm{mg} / \mathrm{kg}$, Fig. $1 A) . N G F I-\mathrm{A}$ mRNA expression also appeared in the tissue surrounding the patches, but in the rostral caudoputamen this signal was much weaker than that in the patches, even in rats treated with the highest doses of amphetamine. The patches of transcript expression were especially prominent in the ventral one-half to two-thirds of the caudoputamen. The patchiness of the NGFI-A mRNA expression gradually diminished at more caudal leveis of the caudoputamen (Fig. $2 A-D$ ), apparently due to a rise in labeling around the patches (see below). With this bicompart- ment labeling, the total intensity of the signal was correspondingly augmented.

This characteristic topography of NGFI-A mRNA expression in response to acute amphetamine treatment was visible in all rats in which a response was detected. The main change in striatal labeling evident with the increasing doses of amphetamine was an increase in intensity and, with this, clearer definition of patches of heightened labeling in the rostral caudoputamen and of labeling in the medial division ("shell") of the nucleus accumbens. Labeling in the dorsolateral caudoputamen tended to be weaker than that elsewhere even at the highest drug doses. The $5 \mathrm{mg} / \mathrm{kg}$ dose was chosen for further detailed study of the mRNA expression after amphetamine because it 

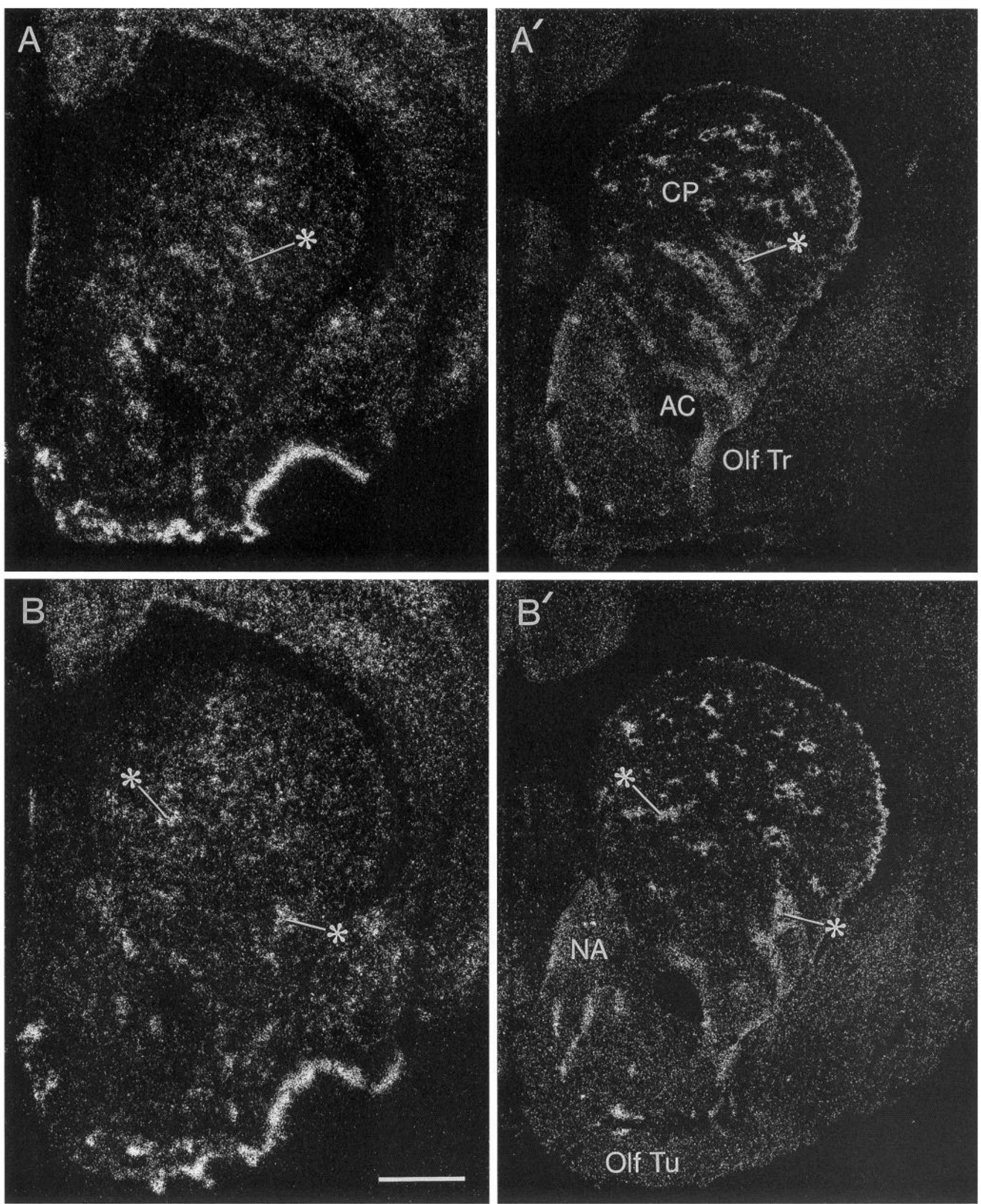

Figure 2. Evidence that the patches of amphetamine-activated NGFI-A mRNA expression in the rostral caudoputamen correspond to striosomes. Left $(A-D)$, In situ autoradiograms illustrating NGFI-A mRNA expression induced by $5 \mathrm{mg} / \mathrm{kg}$ amphetamine $1 \mathrm{hr}$ before brain processing. Right $\left(A^{\prime}-D^{\prime}\right)$, Serially adjoining sections illustrating striosomes as zones of heightened ${ }^{3} \mathrm{H}$-naloxone binding. Asterisks in $A-C$ and $A^{\prime}-C^{\prime}$ indicate examples of matching striosomal patches in the three pairs of sections. Note that the striosomal selectivity of the NGFI-A mRNA induction fades at progressively more caudal levels $(A-C)$. $A C$, anterior commissure; $C P$, caudoputamen; $G P$, globus pallidus; $N A$, nucleus accumbens; $O l f T r$, olfactory tract; Olf Tu, olfactory tubercle; $S$, septum. Scale bar, $1 \mathrm{~mm}$. 

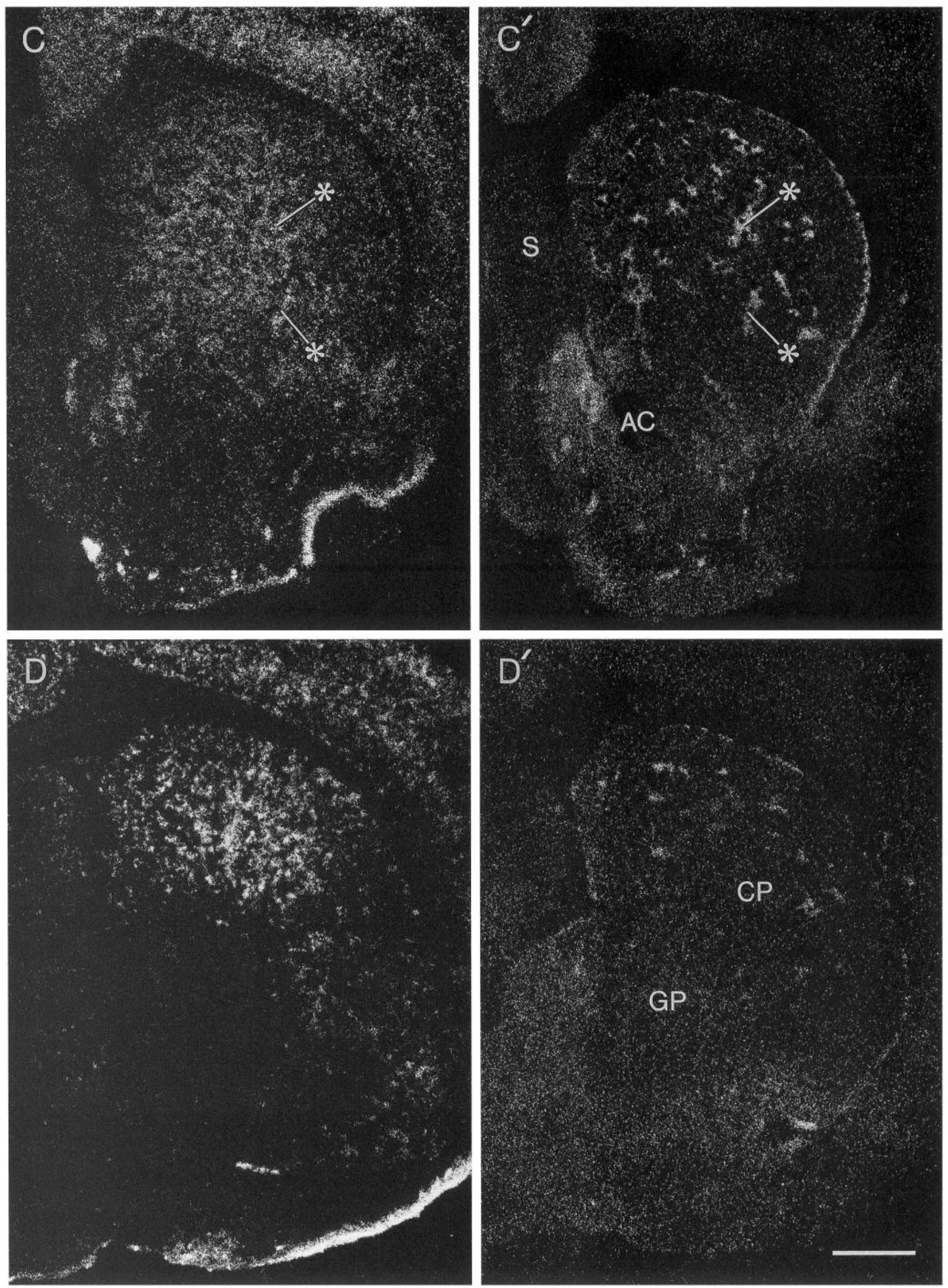

$D^{\prime}$

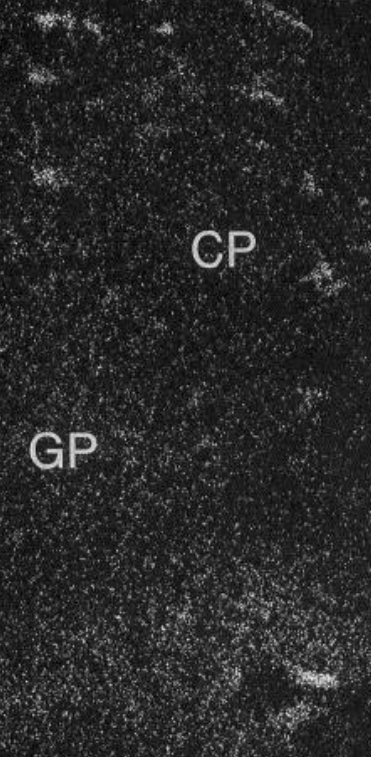



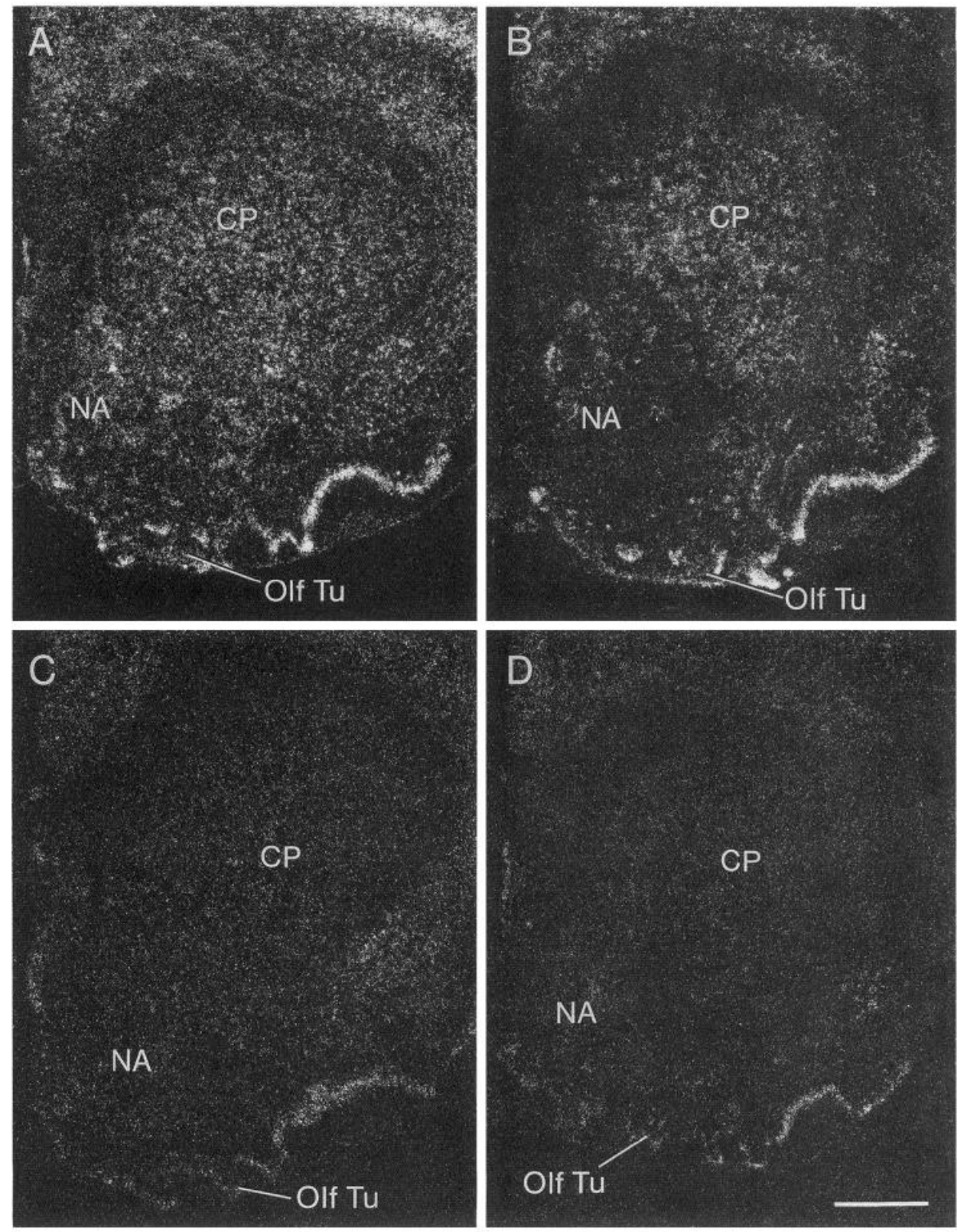

Figure 3. Dose-response series of in situ autoradiograms illustrating $N G F I$-A mRNA expression evoked in the rostral striatum by cocaine at $50 \mathrm{mg} / \mathrm{kg}(A), 25$ $\mathrm{mg} / \mathrm{kg}(B), 10 \mathrm{mg} / \mathrm{kg}(C)$, and $5 \mathrm{mg} / \mathrm{kg}$ (D). Note that the NGFI-A activation involves both striosomes and matrix. Note also that only at the highest doses is there intense activation in the nucleus accumbens septi. Survival times for all animals were $1 \mathrm{hr} . C P$, caudoputamen; $N A$, nucleus accumbens; $O$ lf $T u$, olfactory tubercle. Scale bar, $1 \mathrm{~mm}$.

was the minimum dose that produced a reliable and reproducible signal after the treatment.

\section{Striosomal predominance of heightened NGFI- $A$ mRNA in the rostral caudoputamen of amphetamine-treated rats}

To test whether the localized zones of enhanced NGFI-A mRNA expression in the rostral caudoputamen corresponded to striosomes, we compared the patterns of hybridization to the distribution of ${ }^{3} \mathrm{H}$-naloxone binding in adjoining sections (Fig. 2). Patches of heightened $\mu$-opioid receptor ligand binding labeled with ${ }^{3} \mathrm{H}$-naloxone are known to represent striosomes (Pert et al., 1976; Herkenham and Pert, 1981). As shown in Figure 2, virtually every patch of high NGFI-A mRNA expression corresponded to a patch of heightened ${ }^{3} \mathrm{H}$-naloxone binding. Slight changes in the shapes of the patches of hybridization signal and ligand binding occurred from section to section, but these were systematic and in accord with the three-dimensional continuity of the patches as striosomal labyrinths.
Three details of the serial-section comparisons shown in Figure 2 are worth emphasizing. First, the relative dimensions of the two sets of patches tended to be similar. For example, just as the ${ }^{3} \mathrm{H}$-naloxone-labeled striosomes are larger and less angular in the ventral than in the dorsal caudoputamen, so are the corresponding matches of NGFI-A mRNA hybridization. Second, not all of the ${ }^{3} \mathrm{H}$-naloxone-labeled striosomes had NGFI-A mRNA patches at the $5 \mathrm{mg} / \mathrm{kg}$ dose, but as shown in Figure 1, with higher doses of amphetamine there was increased vividness of the NGFI-A mRNA patches, as if more of the striosomal system were recruited. Third, even at middle and caudal levels of the caudoputamen, where there was increasingly strong induction of NGFI-A in the extrastriosomal matrix, slightly higher levels of hybridization in patches corresponding to ${ }^{3} \mathrm{H}$-naloxone patches often could be detected nonetheless. Thus, NGFI-A mRNA was expressed in large parts of the striosomal system even at caudal levels, but at these levels, transcript expression in the matrix was nearly or fully as strong. 

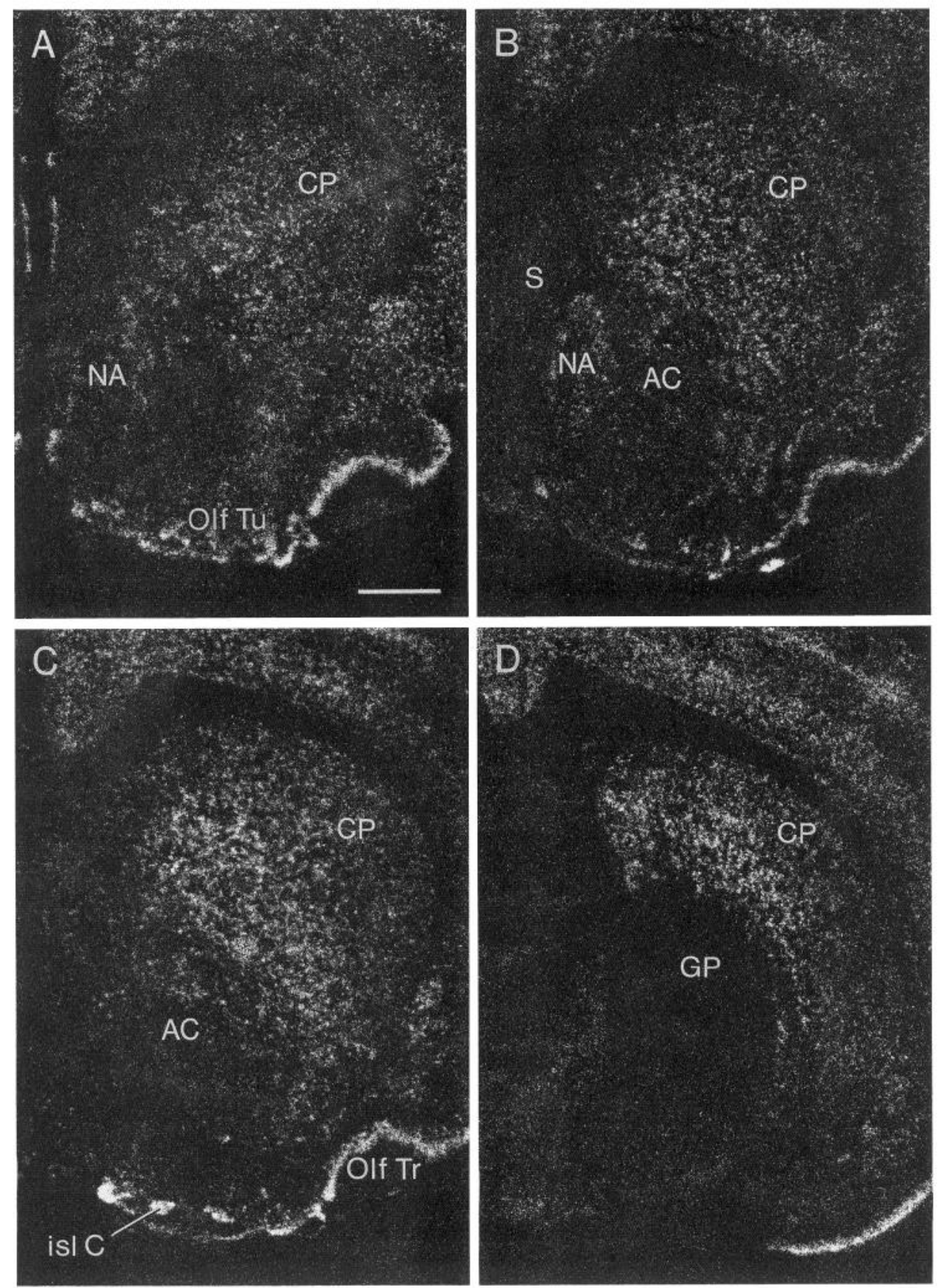

Figure 4. Rostral-to-caudal $(A-D)$ series of in situ autoradiograms illustrating distribution of NGFI-A mRNA induced in striatum by $25 \mathrm{mg} / \mathrm{kg}$ cocaine $\mathrm{l} \mathrm{hr}$ before brain processing. There is strong expression in the medial and central parts of the caudoputamen $(C P)$, whereas there is much less activation in the dorsal and lateral rim of the caudoputamen. Note strong activation of NGFI-A mRNA expression in the islands of Calleja (isl C), but much weaker activation in the nucleus accumbens $(N A)$, especially in its core subdivision. $A C$, anterior commissure; $G P$, globus pallidus; Olf $T r$, olfactory tract; Olf Tu, olfactory tubercle; $S$, septum. Scale bar, $1 \mathrm{~mm}$.
Cocaine-induced expression of NGFI-A in striosome and matrix compartments and in the ventral striatum

Acute treatment with cocaine induced widespread expression of NGFI-A mRNA in the caudoputamen without obvious compartmental heterogeneity at any anteroposterior level (Figs. 3, 4). This diffuse pattern of activation occurred even at the lowest doses given ( 5 and $10 \mathrm{mg} / \mathrm{kg}$ ), after which there was only a weak elevation in hybridization signal relative to control levels (Fig. 3). There was, nevertheless, a marked change in the pattern of NGFI-A mRNA expression with increasing dose: the distribution of heightened mRNA signal became progressively more widespread both in the caudoputamen and in the nucleus accumbens (Fig. 3). In the caudoputamen, $25 \mathrm{mg} / \mathrm{kg}$ produced a pattern of induction that was typically most pronounced in a funnel-shaped zone in the central and medial part of the nucleus. Laterally and dorsally, expression was relatively weak. Farther caudally, the induction was mainly medial (Fig. 4). It was only at the highest dose level $(50 \mathrm{mg} / \mathrm{kg})$ that hybridization signal appeared in the dorsal and lateral periphery of the caudoputamen as well as in its centromedial part. Even so, the peripheral expression of NGFI-A was weaker than that in the central caudoputamen.

A dose-related increase in the distribution of NGFI-A mRNA expression also occurred in the nucleus accumbens (Fig. 3). At $25 \mathrm{mg} / \mathrm{kg}$ cocaine, labeling in the nucleus was mainly in the shell. At the highest dose level $(50 \mathrm{mg} / \mathrm{kg})$, hybridization was strong in both the shell and the core subdivisions of the nucleus. 


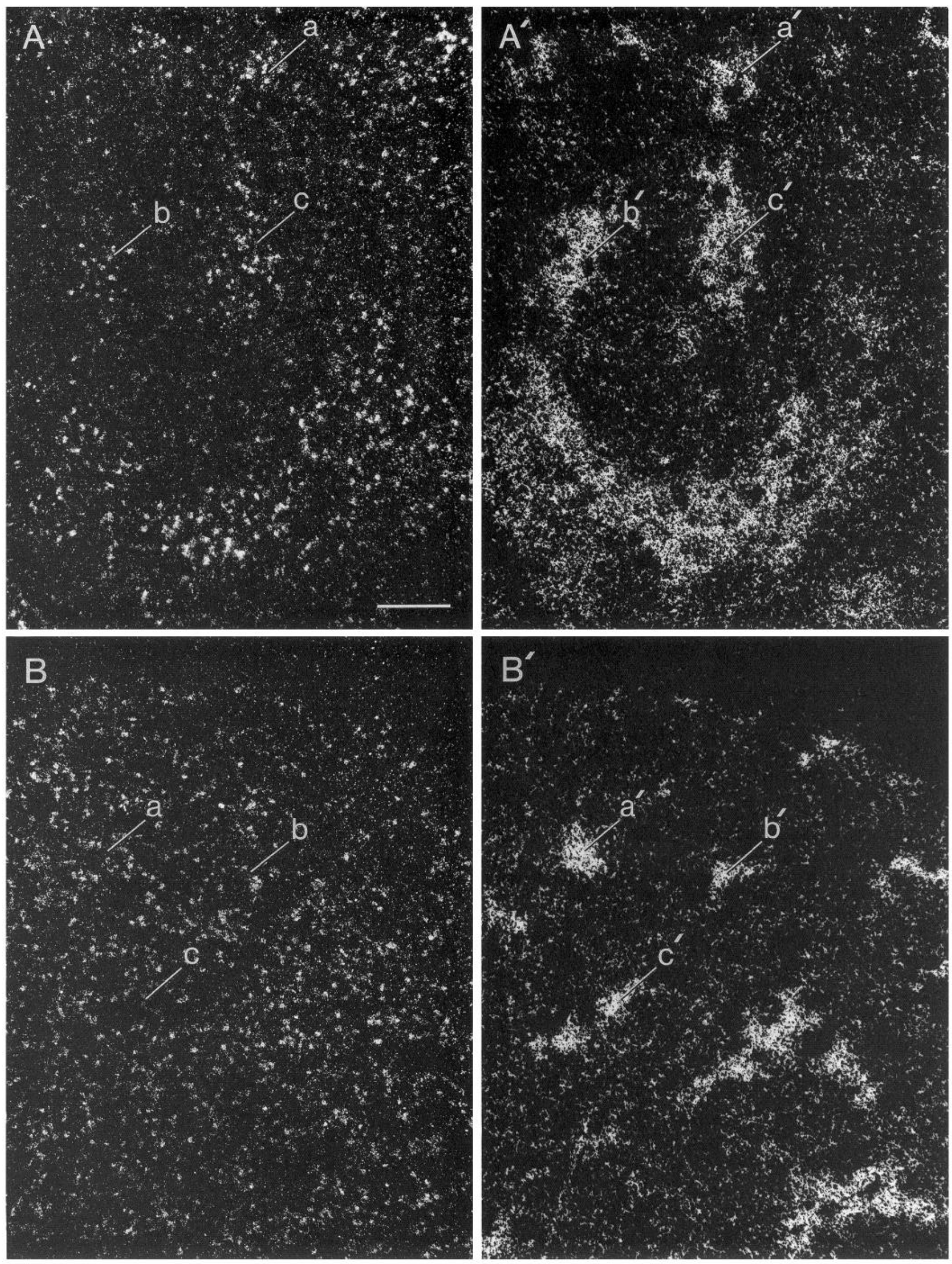


To compare in detail the distributions of NGFI-A mRNA expression induced by cocaine with that induced by amphetamine, we prepared a series of rats treated, respectively, with $25 \mathrm{mg} / \mathrm{kg}$ cocaine or with $5 \mathrm{mg} / \mathrm{kg}$ amphetamine, the lowest dose levels at which consistent strong hybridization patterns appeared in our dose-response analysis. At these doses, the two drugs elicited comparable levels of sniffing and rearing, as reported previously (Scheel-Krüger et al., 1977). In the anterior caudoputamen, $25 \mathrm{mg} / \mathrm{kg}$ of cocaine produced a generalized induction of NGFI-A expression in the central zone of the nucleus, with weak expression laterally and dorsally (Fig. $4 A, B$ ). This pattern of induction was clearly different from that produced by $5 \mathrm{mg} / \mathrm{kg}$ of amphetamine (Fig. $3 A, B$ ), in which a greater breadth of the nucleus contained hybridization signal but the signal had a predominant striosomal distribution. Farther caudally in the caudoputamen, the patterns of induction by cocaine and amphetamine were both relatively diffuse (Figs. $2 C, D ; 4 C, D$ ), but their distributions were still not identical.

\section{Cellular localization of NGFI-A mRNA transcripts}

Figures 5 and 6 illustrate the localization of NGFI-A transcripts visible in emulsion-dipped sections. Confirming the results of the film autoradiography, cells expressing strong NGFI-A mRNA signal were clustered in striosomes in the rostral caudoputamen after amphetamine treatment (Fig. 5A, $A^{\prime}$ ), but were about equally represented in striosomes and matrix in cocaine-treated animals (Fig. $5 B, B^{\prime}$ ). Most of the labeled cells appeared to be the common medium-sized neurons of the striatum, judging from their appearance in sections counterstained for Nissl substance (Fig. 6).

\section{Blockade of both amphetamine-induced and cocaine-induced expression of NGFI-A mRNA in the striatum by SCH23390}

In rats pretreated with the dopamine D1 receptor-selective antagonist $\mathrm{SCH} 23390(0.5 \mathrm{mg} / \mathrm{kg})$, subsequent administration of amphetamine $(5 \mathrm{mg} / \mathrm{kg}, n=4)$ or cocaine $(25 \mathrm{mg} / \mathrm{kg}, n=3)$ failed to induce detectable NGFI-A hybridization in the striatum (Fig. 7A,B). Indeed, even with prolonged autoradiographic exposure times, scarcely any signal was detectable in the striatum. In contrast to NGFI-A mRNA expression in the caudoputamen, expression of NGFI-A mRNA signal in the neocortex and piriform cortex was not abolished by pretreatment with SCH23390. It is not clear whether this cortical expression is constitutive or related to the stress of even gentle handling; Sharp et al. (1991) have found extreme sensitivity of c-fos in cerebral cortex (but not caudoputamen) to such external stimulation.

\section{Discussion}

Regulation of striatal NGFI-A expression by biogenic amines The findings we report here demonstrate that the expression of NGFI-A mRNA in the caudoputamen and the ventral striatum can be regulated by biogenic amine activity. Expression of $N G F I$-A transcripts was markedly enhanced by stimulation with

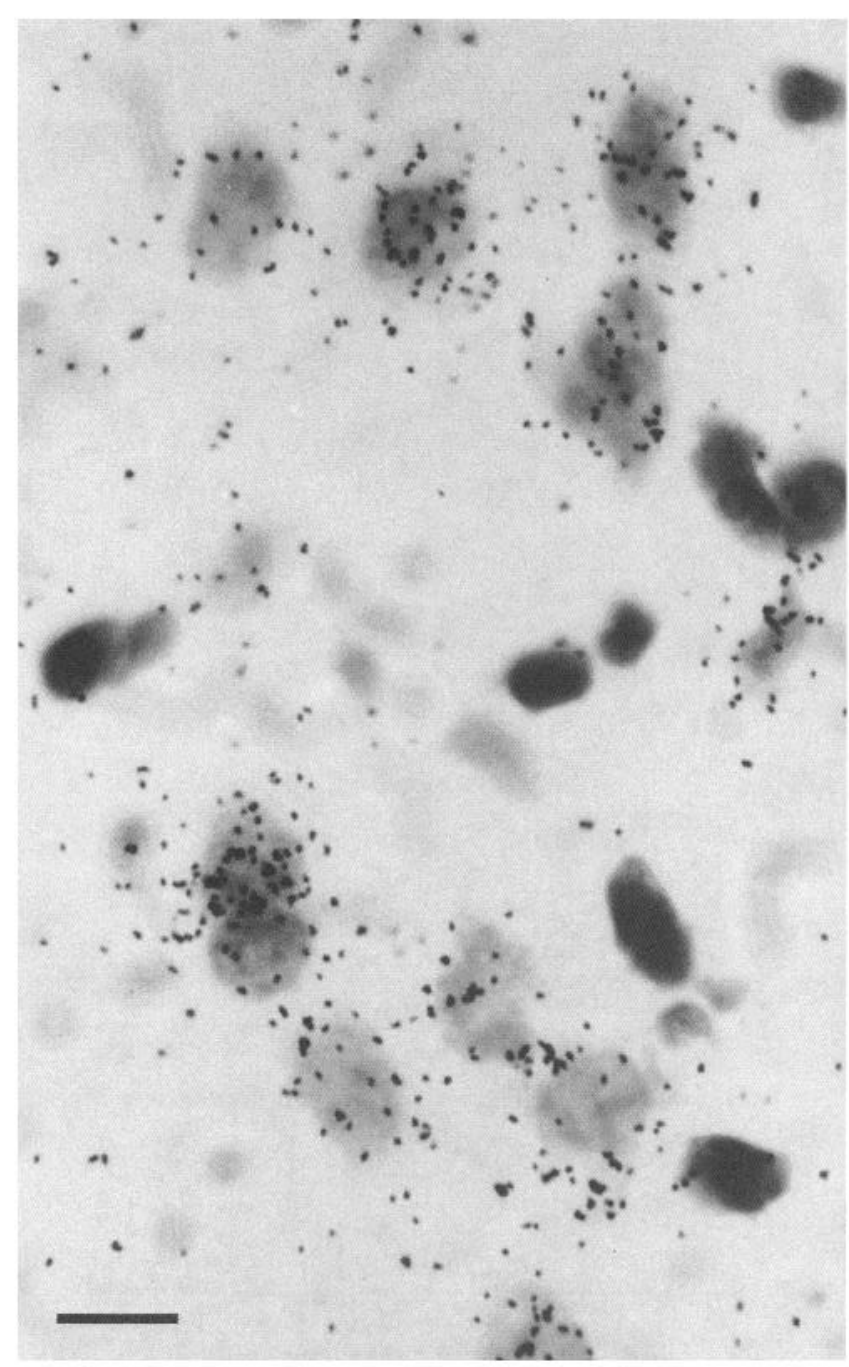

Figure 6. Bright-field photomicrograph demonstrating in situ autoradiographic labeling with NGFI-A mRNA probe of medium-sized neurons in the amphetamine-treated case shown in the dark-field photograph of Figure 5. The neurons are located at the top of the central patch (labeled c) illustrated in Figure $5 A$. Scale bar, $10 \mu \mathrm{m}$.

either of two indirect dopamine agonists, and this enhanced expression was blocked by prior administration of the dopamine receptor antagonist $\mathrm{SCH} 23390$. This pharmacological profile makes it likely that dopamine D1-like receptor activation was a principal inducing stimulus for the increase in NGFI-A expression. Our findings do not rule out a serotonergic component in the genomic response, however, for SCH23390 also is known to bind to serotonergic receptors in the rodent brain (Bischoff et al., 1986). Nor do our findings rule out the possibility that dopamine D1-like receptors other than the pharmacologically defined D1 subtype are blocked by SCH23390 and participate in the signaling pathway (Sokoloff et al., 1990; Sunahara et al., 1991; Van Tol et al., 1991), including particularly the newly

Figure 5. Photomicrographs of NGFI-A mRNA in situ autoradiograms from emulsion-dipped sections ( $A$ and $B$, respectively) and from serially adjacent sections processed for ${ }^{3} \mathrm{H}$-naloxone binding ( $A^{\prime}$ and $B^{\prime}$, respectively) illustrating disposition of $N G F I$-A mRNA-positive-striatal cells following $5 \mathrm{mg} / \mathrm{kg}$ amphetamine exposure $\left(A, A^{\prime}\right)$ and $25 \mathrm{mg} / \mathrm{kg}$ cocaine exposure $\left(B, B^{\prime}\right)$. Note that most of the $N G F I$-A mRNA-positive cells in the amphetamine case are in striosomes ( $a-c$ and $a^{\prime}-c^{\prime}$ indicate three corresponding pairs of patches). By contrast, in the cocaine-treated case, labeled cells are in both striosomes and matrix ( $a-c$ and $a^{\prime}-c^{\prime}$ indicate three examples of corresponding striosomal loci). Survival times, $1 \mathrm{hr}$. Scale bar, $200 \mu \mathrm{m}$. 

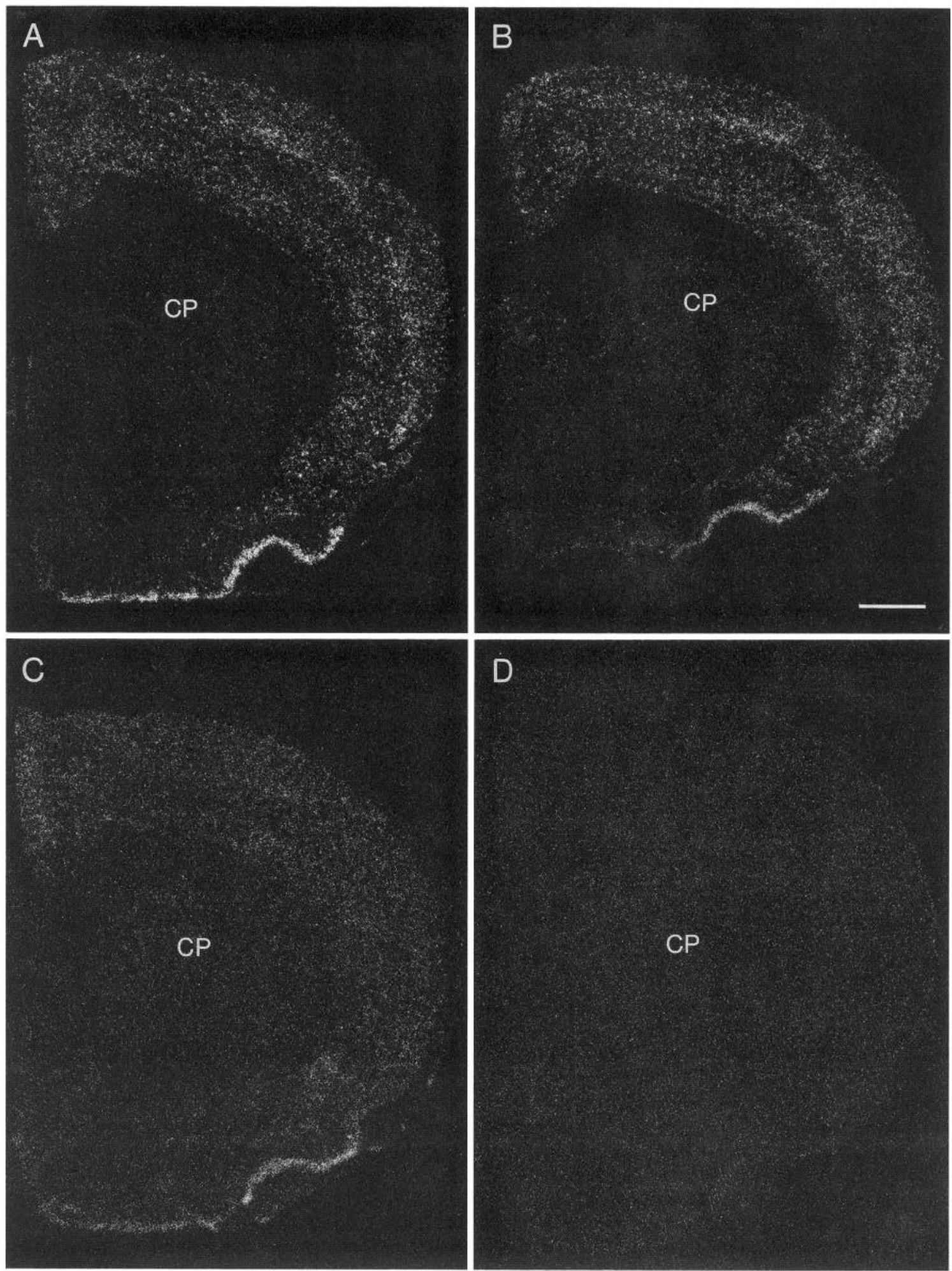

Figure 7. In situ autoradiograms from representative control experiments. $A$ and $B$, In rats pretreated with the D1-selective dopamine receptor antagonist SCH $23390(0.5 \mathrm{mg} / \mathrm{kg})$, there was blockade of the intrastriatal induction of $N G F I-\mathrm{A}$ mRNA expression both by amphetamine (5 mg/ $\mathrm{kg}, A)$ and by cocaine $(25 \mathrm{mg} / \mathrm{kg}, B)$. Note that expression of $N G F I-A$ mRNA in the cerebral cortex was not blocked. $C$, Saline injection induced little if any NGFI-A mRNA expression in the striatum. D, No hybridization signal was seen when the sense probe for NGFI-A was used. The section illustrated is from the brain of a rat treated with amphetamine $(5 \mathrm{mg} / \mathrm{kg}) . C P$, caudoputamen. Scale bar, $1 \mathrm{~mm}$. 
cloned DS dopamine receptor, whose forebrain distribution is reported to resemble that of the D1 receptor (Sunahara et al., 1991). Only when agonist and antagonist drugs specific to cloned dopamine receptor subtypes become available will it be possible to identify fully the pharmacological specificity of the psychostimulant effects shown here. We did not test the effects of dopamine D2-selective antagonists. We and others have found that $\mathrm{D} 2$ receptor antagonists themselves can induce immediateearly gene induction in the caudoputamen (Dragunow et al., 1990; Graybiel et al., 1990; Miller, 1990), and Miller (1990) has shown that D2 agonist treatment can block the induction of c-fos mRNA produced by D2 antagonists.

\section{Compartmental selectivity of the NGFI-A response}

The most striking finding of our study was that the two indirect dopamine agonists we administered, amphetamine and cocaine, produced different patterns of NGFI-A expression in the caudoputamen and ventral striatum. Rostrally in the caudoputamen, amphetamine induced NGFI-A mRNA expression preferentially in the striosomal compartment of the striatum. This effect was not dose related, as the striosomal pattern was observed with the highest dose tested $(15 \mathrm{mg} / \mathrm{kg})$ that led to induce the gene as well as with the lowest dose $(2 \mathrm{mg} / \mathrm{kg})$. The pattern induced by cocaine, even at the lowest dose $(5 \mathrm{mg} / \mathrm{kg})$, was not compartment selective. The basis of these differences is not clear, but could involve the different mechanisms by which the two drugs increase extracellular biogenic amines. Amphetamine has the predominant effect of releasing biogenic amines (Moore, 1978; Zetterström et al., 1983), whereas cocaine principally blocks catecholamine reuptake (Taylor and Ho, 1978; Vickroy and Johnson, 1982; Kilty et al., 1991). These modes of action could produce contrasts in the synaptic concentrations of amine generated, the proportion of synaptic versus extrasynaptic concentrations of amine present, and the temporal pattern of druginduced increases in amine. The cffcets could also reflect indirect effects on vascular supply, enhancing or diminishing the turnover of amine. As we gave the drugs intraperitoneally, the contrasting compartmental patterns of induction could reflect either differences in the responses to stimulation of receptors in the caudoputamen (e.g., depending on densities of high-affinity uptake sites and/or receptors in striosomes and matrix), or differences in responsiveness at sites projecting to the caudoputamen, or both (see below).

The regional selectivity for striosomal $N G F I-\mathrm{A}$ mRNA activation that we observed in the amphetamine-treated animals is similar to the patterns we have observed in amphetaminetreated rats by immunohistochemistry with polyclonal antisera raised against peptide sequences in Fos (Graybiel et al., 1990). Following acute amphetamine at the same doses, Fos-like immunoreactivity is preferentially expressed in striosomes rostrally but in both striosomcs and matrix caudally. Furthermore, the sharpness of the striosomal delineations with the Fos-like immunoreactivity is roughly similar to that seen with the $N G F I$-A probes. Interestingly, however, in ongoing in situ hybridization studies of $\mathrm{c}-f \circ s$ and $j u n-\mathrm{B}$ expression induced by amphetamine (R. Moratalla and A. M. Graybiel, unpublished observations), we have not observed as sharp a delineation of striosomes as evident with NGFI-A hybridization or Fos-like immunoreaction. This suggests that the NGFI-A mRNA response selectivity for the striosomal system may be particularly marked, and may be paralleled by some but not other members of the fos/jun family (Cohen and Curran, 1988; Cohen et al.,
1989; Nishina et al., 1990). The differential compartmental expression of NGFI-A mRNA in the response of striatal neurons to amphetamine thus may be not only stimulus specific, but also gene specific. The D1-like receptor selectivity of the effects suggests that stimulation of CRE (cAMP responsive element) could be involved, and both NGFI-A and c-fos have at least one CRE in their regulatory regions (Tsai-Morris et al., 1988; Herschman, 1991). The NGFI-A gene is reported to have two CRE sites, whereas c-fos has only one. The NGFI-A promotor is also notable for having five serum response element (SRE) sites, as compared to one for the c-fos promotor (Tsai-Morris et al., 1988; Herschman, 1991). Conceivably, these differences could account for the gene selectivity we observe.

\section{Molecular signaling pathways in striosome and matrix compartments of the striatum}

The fact that NGFI-A mRNA and Fos-like transcription factors show similar drug-specific compartmental and regional patterns of enhanced expression in the striatum raises the possibility that there are functionally distinct molecular signaling pathways in striosomes and matrix. If so, understanding the signaling pathways leading to selective immediate-early gene responses may be key to determining the molecular specificity of the striosomal system. Finding out more about these signaling pathways could also have considerable practical significance, as drugs then could be designed to act selectively on these two neurochemical compartments of the striatum.

There are clues to what these signaling pathways might be, but no definitive evidence. Both compartments express the neurotransmitter substances characteristic of aminergic transmission, but to different degrees. In primates and cats, striosomes tend to have more D1-like but less D2-like dopamine receptorselective ligand binding (Joyce et al., 1986; Besson et al., 1988), lower catecholamine transporter-related binding (Graybiel and Moratalla, 1989; Lowenstein et al., 1990), lower tyrosine hydroxylase-like immunoreactivity (Ferrante and Kowall, 1987; Graybiel et al., 1987), lower 5-HT-like immunoreactivity (Lavoie and Parent, 1990), and higher immunostaining for markers of the phosphoinositide second messenger system (Fotuhi et al., 1991) than nearby parts of the matrix.

These characteristics suggest that adenylate cyclase and/or phosphoinositide pathways could be differentially active in striosomes and matrix. Curiously, the compartmentalization of many of these substances is not as striking in the rat's caudoputamen except during development (Olson et al., 1972; Tennyson et al., 1972; Butcher and Hodge, 1976; Kent et al., 1982; van der Kooy, 1984; Foster et al., 1987; Voorn et al., 1988; Happe and Murrin, 1989; Loopuijt, 1989). Pharmacological treatments affecting dopamine and other biogenic amines can nevertheless induce highly compartmental changes in expression of neuropeptides in the caudoputamen of the rat (see below). Apparently, the anatomical markers so far available for localization studies do not adequately demonstrate differential actions of the biogenic amines on the striosomes and surrounding matrix in the rat. As we report here, these compartmental effects as viewed by immediate-early gene responses can be marked, particularly in the rostral part of the caudoputamen.

Differences in the connections of striosomes and matrix could also account for the different patterns of NGFI-A activation by amphetamine and cocaine. In the rostral caudoputamen of the rat, for example, where the striosomal activation of NGFI-A was most pronounced in response to amphetamine challenge, 
striosomes receive a particularly dense projection from part of the prefrontal cortex, which itself receives a dopaminergic innervation (Donoghue and Herkenham, 1986; Gerfen, 1989; Sesack et al., 1989). Striosomes and matrix in this species also receive compartment-selective inputs from parts of the thalamus and amygdala that are linked indirectly to midbrain aminergic groups (Jones et al., 1988; Wallace et al., 1989; Cornwall et al., 1990; Gonzales and Chesselet, 1990; Kita and Kitai, 1990; Berendse, 1991). Finally, striosomes and matrix are innervated by different populations of midbrain dopaminc-containing neurons in the rat, as in other species (Gerfen et al., 1987; JiménezCastellanos and Graybiel, 1987; Langer and Graybiel, 1989). Each of these afferent systems could be affected directly or indirectly by dopamine agonist treatments, so that the striosomeselective effects of amphetamine could themselves be indirect (e.g., via part of the prefrontal cortex or thalamus) rather than occurring as the result of a direct action of amphetamine on amine release in the caudoputamen.

\section{Neuropeptide regulation as a possible consequence of NGFI-A activation in the striatum}

Pronounced changes in peptide expression occur in the striatum following chronic treatments with dopamine agonists and antagonists, and also following lesions or stimulation of dopaminergic mesostriatal fiber systems (see Graybiel, 1990, for review; Gerfen et al., 1990, 1991; Jiang et al., 1990). Somc of these changes result in a sharp increase in the detectability of peptide-positive patches - in some instances through a documented selective increase in neuropeptide expression in patches corresponding to striosomes. Such large, patchy upswings in neuropeptide expression in striosomes have been found for neurotensin-like immunoreactivity following extended reserpine pretreatment (Bean et al., 1989) and for dynorphin-like immunoreactivity (Sivam et al., 1987; Jiang et al., 1990; Gerfen et al., 1991) and prodynorphin mRNA hybridization (Gerfen et al., 1991) following chronic apomorphine treatment. The fact that alterations in mRNA expression are found suggests that changes in gene transcription or in mRNA stabilization are induced.

In the experiments we report here, expression of $N G F I-\mathrm{A}$ transcripts was weak or nil at the lowest doses of amphetamine and cocaine that we administered. Physiological and bchavioral effects of these drugs are nevertheless known to occur at such doses (Randrup and Munkvad, 1974; Sharp et al., 1987). This difference makes it difficult to approach correlations between our findings and those on the physiology. The regional and neuronal specificity of the induction we see may nevertheless indicate functional specializations.

One interesting possibility is that the early responses to dopamine agonists seen by monitoring changes in expression of NGFI-A mRNA and other immediate-early genes could lead to a systematic series of longer-term changes in gene transcription in the striatum and that, in particular, these could include compartment-selective changes in neuropeptide and neuropeptide mRNA levels observed in the caudoputamen. A major difference in the paradigms eliciting the immediate-early gene and neuropeptide gene responses is the duration of the stimulus. We see greatly increased expression of $N G F I-\Lambda$ mRN $\Lambda$ within an hour of intraperitoneal injection of dopamine agonists, whereas the effects of dopamine agonist treatments on neuropeptide mRNA levels are found after prolonged (10-14 d) exposures. Interestingly, however, Grimes et al., (1990) have re- ported that after chronic exposure to the direct dopamine agonist apomorphine, Fos-like immunoreactivity is induced selectively in striosomes in less than $2 \mathrm{hr}$ following the final treatment, and such chronic treatments are known to produce upregulation of dynorphin immunoreactivity and prodynorphin mRNA in patches in the caudoputamen that correspond to striosomes (Gerfen et al., 1991). The apparent parallel in distribution of the Fos and peptide responses to chronic apomorphine exposure suggests a strong correlation between these immediate-early gene and peptide gene responses and raises the possibility that the effects could reflect a common signaling pathway. A similar point has already been made in respect to parallel regulation of fos/jun family immediate-early genes and dynorphin in the spinal cord (Draisci and Iadarola, 1989; Naranjo et al., 1991; see also Gogas et al., 1991). The NGFI-A response in striosomes on exposure to amphetamine could be another early response in the signaling pathway leading to dynorphin regulation, given that-at least in the cat-striosomal neurons have enhanced expression of dynorphin relative to matrix neurons (Graybiel and Chesselet, 1984; Besson et al., 1990). Tachykinins could also be implicated. Tachykinin (substance P)-like peptides almost invariably coexist with dynorphin-like peptides in neurons of the caudoputamen (Besson et al., 1990, 1991; Reiner and Anderson, 1990). Kohno et al. (1984) suggest that there is a distinctly patchy distribution of neurons expressing substance P-like (tachykinin-like) immunoreactivity rostrally, but not caudally, in the rat's caudoputamen. This pattern is remarkably reminiscent of the $N G F I-\mathrm{A} \mathrm{mRNA}$ activation patterns induced by amphetamine.

\section{Cooperativity in transcriptional activation of striatal neurons}

The evidence we report here, combined with findings from other recent studies (Cole et al., 1990; Graybiel et al., 1990; Young et al., 1991), demonstrates unequivocally that mRNA transcripts of at least two families of immediate-early genes can be activated in the striatum by dopamine agonists, and that the patterns of activation have highly similar anatomical, and therefore possibly functional, specificity. Molecular mapping studies suggest that the known genes of the leucine zipper and zinc finger families may have different constellations of upstream elements influencing their promotor sites (see, e.g., Tsai-Morris et al., 1988; Janssen-Timmen et al., 1989), and that their gene products can act in different combinatorial patterns. The particular impact of the present results is the suggestion that this combinatorial complexity at the molecular level may be played out in the basal ganglia so as to allow different patterns of positive or negative cooperativity of genes responding to stimuli ultimately affecting the same neurotransmitter system. If so, this highly differentiated immediate-early gene response may un. derlie some of the complexity evident in the eventual functionai response of the basal ganglia to modulation by dopamine.

\section{References}

Bean AJ, During MG, Deutch A, Roth RH (1989) Effects of dopamine depletion on striatal neurotensin: biochemical and immunohistochemical studies. J Neurosci 9:4430-4438.

Berendse HW (1991) Regional specificity of ventral striatal connections in the rat. Amsterdam: Vrije University.

Besson M-J, Graybiel AM, Nastuk MA (1988) [ $\left.{ }^{3} \mathrm{H}\right]-\mathrm{SCH} 23390$ binding to $D_{1}$ dopamine receptors in the basal ganglia of the cat and primate: delineation of striosomal compartments and pallidal and nigral subdivisions. Neuroscience 26:101-119.

Besson M-J, Graybiel AM, Quinn B (1990) Coexpression of neuro- 
peptides in the cat's striatum: an immunohistochemical study of substance $P$, dynorphin B and enkephalin. Neuroscience 39:33-58.

Besson M-J, Graybiel AM, Quinn B (1991) Coexpression of neuropeptides and glutamic acid decarboxylase in cat striatal neurons: dependence on striosomal compartmentation. In: The basal ganglia, III (Bernardi G, Carpenter MB, di Chiara G, Morelli M, Stanzione P, eds), pp 29-39. New York: Plenum.

Bischoff S, Heinrich M, Sonntag JM, Krauss J (1986) The D-1 dopamine receptor antagonist SCH 23390 also interacts with brain serotonin (5- $\mathrm{HT}_{2}$ ) receptors. Eur J Pharmacol 129:367-370.

Butcher LL, Hodge GK (1976) Postnatal development of acetylcholinesterase in the caudate-putamen and substantia nigra of rats. Brain Res 106:223-240.

Christy BA, Lau LF, Nathans D (1988) A gene activated in mouse $3 \mathrm{~T} 3$ cells by serum growth factors encodes a protein with "zinc-finger" sequences. Proc Natl Acad Sci USA 85:7857-7861.

Cohen DR, Curran T (1988) Fra-1: a serum-inducible, cellular immediate-early gene that encodes a Fos-related antigen. Mol Cell Biol 8:2063-2069.

Cohen DR, Ferreira PCP, Gentz R, Franza BR Jr, Curran T (1989) The product of a fos-related gene, fra-1, binds cooperatively to the AP-1 site with Jun: transcription factor AP-1 is comprised of multiple protein complexes. Genes Dev 3:173-184.

Cole AJ, Saffen DW, Baraban JM, Worley PF (1989) Rapid increase of an immediate-early gene messenger RNA in hippocampal neurons by synaptic NMDA reccptor activation. Naturc 340:474-476.

Cole AJ, Worley PF, Baraban JM (1990) Dopaminergic regulation of transcription factor mRNAs in striatal neurons in vivo. Soc Neurosci Abstr 16:800.

Cornwall J, Cooper JD, Phillipson OT (1990) Afferent and efferent connections of the laterodorsal tegmental nucleus in the rat. Brain Res Bull 25:271-284.

DeLong MR, Georgopoulos AP (1981) Motor functions of the basal ganglia. In: Handbook of physiology, Sect 1, Vol 2, Pt 2 (Brooks VB, ed), pp 1017-1081. Baltimore: Williams and Wilkins.

Donoghue JP, Herkenham M (1986) Neostriatal projections from individual cortical fields conform to histochemically distinct striatal compartments in the rat. Brain Res 365:397-403.

Dragunow M, Robertson HA (1987) Kindling stimulates c-fos protein(s) in granule cells of the rat dentate gyrus. Nature 329:441-442.

Dragunow M, Robertson GS, Faull RLM, Robertson HA, Jansen K (1990) D2 dopamine receptor antagonists induce fos and related proteins in rat striatal neurons. Neuroscience 37:287-294.

Draisci G, Iadarola MJ (1989) Temporal analysis of increases in c-fos, preprodynorphin and preproenkephalin mRNAs in rat spinal cord. Mol Brain Res 6:31-37.

Ferrante RJ, Kowall NW (1987) Tyrosine hydroxylase-like immunoreactivity is distributed in the matrix compartment of normal human and Huntington's disease striatum. Brain Res 416:141-146.

Foster GA, Schultzberg M, Hökfelt T, Goldstein M, Hemmings HC Jr, Ouimet CC, Walaas SI, Greengard P (1987) Devclopment of a dopamine- and cyclic adenosine $3^{\prime}: 5^{\prime}$-monophosphate-regulated phosphoprotein (DARPP-32) in the prenatal rat central nervous system, and its relationship to the arrival of presumptive dopaminergic innervation. J Neurosci 7:1994-2018.

Fotuhi M, Dawson TM, Sharp AH, Martin LJ, Graybiel AM, Snyder SH (1991) The phosphoinositide second messenger system is enriched in striosomes of the primate striatum. Soc Neurosci Abstr 17: 854 .

Gauchy C, Kemel ML, Desban M, Romo R, Glowinski J, Besson M-J (1987) The role of dopamine released from distal and proximal dendrites of nigrostriatal dopaminergic neurons in the control of GABA transmission in the thalamic nucleus ventralis medialis in the cat. Neuroscience 22:935-946.

Gerfen CR (1989) The neostriatal mosaic: striatal patch-matrix organization is related to cortical lamination. Science 246:385-388.

Gerfen CR, Herkenham M, Thibault J (1987) The neostriatal mosaic. II. Patch- and matrix-directed mesostriatal dopaminergic and nondopaminergic systems. J Neurosci 7:3915-3934.

Gerfen CR, Engber TM, Mahan LC, Susel Z, Chase TN, Monsma FJ Jr, Sibley DR (1990) D1 and D2 dopamine receptor-regulated gene expression of striatonigral and striatopallidal neurons. Science 250 : 1429-1432.

Gerfen CR, McGinty JF, Young WS III (1991) Dopamine differentially regulates dynorphin, substance $P$, and enkephalin expression in striatal neurons: in situ hybridization histochemical analysis. J Neurosci 11:1016-1031.

Gogas KR, Presley RW, Levine JD, Basbaum AI (1991) The antinociceptive action of supraspinal opioids results from an increase in descending inhibitory control: correlation of nociceptive behavior and c-fos expression. Neuroscience 42:617-628.

Gonzales C, Chesselet M-F (1990) Amygdalonigral pathway: an anterograde study in the rat with Phaseolus vulgaris leucoagglutinin (PHA-L). J Comp Neurol 297:182-200.

Graybiel AM (1990) Neurotransmitters and neuromodulators in the basal ganglia. Trends Neurosci 13:244-254.

Graybiel AM, Chesselet M-F (1984) Striatal cell bodies expressing dynorphin B-like (DYN) and met-enkephalin-like (ENK) immunoreactivities have complementary distributions in kittens and contrasting distributions in cats. Soc Neurosci Abstr 10:514.

Graybiel AM, Moratalla R (1989) Dopamine uptake sites in the striatum are distributed differentially in striosome and matrix compartments. Proc Natl Acad Sci USA 86:9020-9024.

Graybiel AM, Hirsch EC, Agid YA (1987) Differences in tyrosine hydroxylase-like immunoreactivity characterize the mesostriatal innervation of striosomes and extrastriosomal matrix at maturity. Proc Natl Acad Sci USA 84:303-307.

Graybiel AM, Moratalla R, Robertson HA (1990) Amphetamine and cocaine induce drug-specific activation of the c-fos gene in striosomematrix and limbic subdivisions of the striatum. Proc Natl Acad Sci USA 87:6912-6916.

Grimes LM, Ping X, Jiang H-K, Hong J-S (1990) Striatal patch/matrix distribution of Fos, substance $P$ and dynorphin induced by apomorphine in intact and 6-OHDA lesioned rats. Soc Neurosci Abstr 16: 800.

Happe HK, Murrin LC (1989) Development of cholinergic terminals in rat striatum as visualized by $\left[{ }^{3} \mathrm{H}\right]$-hemicholinium-3 autoradiography. Soc Neurosci Abstr 15:293.

Herkenham M, Pert CB (1981) Mosaic distribution of opiate receptors, parafascicular projections and acetylcholinesterase in rat striatum. Nature 291:415-418.

Herschman HR (1991) Primary response genes induced by growth factors and tuner promoters. Annu Rev Biochem 60:281-319.

Hunt SP, Pini A, Evan $G$ (1987) Induction of $c-$ fos-like protein in spinal cord neurons following sensory stimulation. Nature 328:632634.

Janssen-Timmen U, Lemaire P, Mattei M-G, Revelant O, Charnay P (1989) Structure, chromosome mapping and regulation of the mouse zinc-finger gene Krox-24; evidence for a common regulatory pathway for immediate-early serum-response genes. Gene 80:325-336.

Jiang H-K, McGinty JF, Hong J-S (1990) Differential modulation of striatonigral dynorphin and enkephalin by dopamine receptor subtypes. Brain Res 507:57-64.

Jiménez-Castellanos J, Graybiel AM (1987) Subdivisions of the dopamine-containing A8-A9-A10 complex identified by their differential mesostriatal innervation of striosomes and extrastriosomal matrix. Neuroscience 23:223-242.

Jones MW, Kilpatrick IC, Phillipson OT (1988) Thalamic control of subcortical dopamine function in the rat and the effects of lesions applied to the medial prefrontal cortex. Brain Res 475:8-20.

Joyce JN, Sapp DW, Marshall JF (1986) Human striatal dopamine receptors are organized in compartments. Proc Natl Acad Sci USA 83:8002-8006.

Kemel M-L, Desban M, Glowinski J, Gauchy C (1989) Distinct presynaptic control of dopamine release in striosomal and matrix areas of the cat caudate nucleus. Proc Natl Acad Sci USA 6:9006-9010.

Kent JL, Pert CB, Herkenham M (1982) Ontogeny of opiate receptors in rat forebrain: visualization by in vitro autoradiography. Dev Brain Res 2:487-504.

Kilty JE, Lorang D, Amara SG (1991) Cloning and expression of a cocaine-sensitive rat dopamine transporter. Science 254:578-579.

Kita H, Kitai ST (1990) Amygdaloid projections to the frontal cortex and the striatum in the rat. J Comp Neurol 298:40-49.

Kohno J, Shiosaka S, Shinoda K, Inagaki S, Tohyama M (1984) Two distinct strio-nigral substance $P$ pathways in the rat: an experimental immunohistochemical study. Brain Res 308:309-317.

Langer LF, Graybiel AM (1989) Distinct nigrostriatal projection systems innervate striosomes and matrix in the primate striatum. Brain Res 498:344-350.

Lau LF, Nathans D (1987) Expression of a set of growth-related im- 
mediate early genes in BALB/c 3T3 cells: coordinate regulation with c-fos or c-myc. Proc Natl Acad Sci USA 84:1182-1 186.

Lavoie B, Parent A (1990) Immunohistochemical study of the serotoninergic innervation of the basal ganglia in the squirrel monkey. $J$ Comp Neurol 299:1-16.

Lemaire P, Revelant O, Bravo R, Charnay P (1988) Two mouse genes encoding potential transcription factors with identical DNA-binding domains are activated by growth factors in cultured cells. Proc Natl Acad Sci USA 85:4691-4695.

Loopuijt LD (1989) Distribution of dopamine D-2 receptors in the rat striatal complex and its comparison with acetylcholinesterase. Brain Res Bull 22:805-817.

Lowenstein PR, Joyce JN, Coyle JT, Marshall JF (1990) Striosomal organization of cholinergic and dopaminergic uptake sites and cholinergic $M_{1}$ receptors in the adult human striatum: a quantitative receptor autoradiographic study. Brain Res 510:122-126.

Milbrandt J (1987) A nerve growth factor-induced gene encodes a possible transcriptional regulatory factor. Science 238:797-799.

Miller JC (1990) Induction of c-fos mRNA expression in rat striatum by neuroleptic drugs. J Neurochem 54:1453-1455.

Misgeld U, Frotscher M, Wagner A (1984) Identification of projecting neurons in rat neostriatal slices. Brain Res 299:367-370.

Moore KE (1978) Amphetamines: biochemical and behavioural actions in mammals. In: Handbook of psychopharmacology, Vol II (Iversen LL, Iversen SD, Snyder SH, eds), pp 41-98. New York: Plenum.

Moratalla R, Robertson HA, DiZio PA, Graybiel AM (1990) Parallel induction of $j u n \mathrm{~B}$ and $\mathrm{c}-f \circ s$ evoked in the striatum by the psychomotor stimulant drugs cocaine and amphetamine. Soc Neurosci Abstr 16:953.

Morgan JI, Cohen DR, Hempstead JL, Curran T (1987) Mapping patterns of c-fos expression in the central nervous system after seizure. Science 237:192-197.

Naranjo JR, Mellström B, Achaval M, Sassone-Corsi P (1991) Molecular pathways of pain: fos/jun-mediated activation of a noncanonical AP-1 site in the prodynorphin gene. Neuron 6:607-617.

Nisenbaum ES, Stricker EM, Zigmond MJ, Berger TW (1988) Longterm effects of dopamine-depleting brain lesions on spontaneous activity of type II striatal neurons: relation to behavioral recovery. Brain Res 493:389-393.

Nishina H, Sato H, Suzuki T, Sato M, Iba H (1990) Isolation and characterization of $f r a-2$, an additional member of the fos gene family. Proc Natl Acad Sci USA 87:3619-3623.

Olson L, Seiger A, Fuxe K (1972) Heterogeneity of striatal and limbic dopamine innervation: highly fluorescent islands in developing and adult rats. Brain Res 44:283-288.

Pert CB, Kuhar MJ, Snyder SH (1976) Opiate receptors: autoradiographic localization in rat brain. Proc Natl Acad Sci USA 73:37293733.

Ragsdale CW, Graybiel AM (1988) Fibers from the basolateral nucleus of the amygdala selectively innervate striosomes in the caudate nucleus of the cat. J Comp Neurol 269:506-522.

Randrup A, Munkvad I (1974) Pharmacology and physiology of stereotyped behaviour. J Psychiatr Res 11:1-10.

Reiner A, Anderson KD (1990) The patterns of neurotransmitter and neuropeptide co-occurrence among striatal projection neurons: conclusions based on recent findings. Brain Res Rev 15:251-265.

Robertson HA, Peterson MR, Murphy K, Robertson GS (1989) D1 dopamine receptor agonists selectively activate striatal c-fos independent of rotational behavior. Brain Res 503:346-349.

Saffen DW, Cole AJ, Worley PF, Christy BA, Ryder K, Baraban JM (1988) Convulsant-induced increase in transcription factor messenger RNAs in rat brain. Proc Natl Acad Sci USA 85:7795-7799.

Sagar SM, Sharp FR, Curran T (1988) Expression of c-fos protein in brain: metabolic mapping at the cellular level. Science 240:13281331.

Scheel-Krüger J, Braestrup C, Nielson M, Golembiowska K, Mogilnicka E (1977) Cocaine: discussion on the role of dopamine in the biochemical mechanism of action. In: Cocaine and other stimulants (Fllinwood EH Jr, Kilbey MM, eds), pp 373-407. New York: Plenum.

Schlingensiepen K-H, Luno K, Brysch W (1991) High basal expression of the zif268 immediatc carly gene in cortical layers IV and VI, in $\mathrm{CAl}$ and in the corpus striatum - an in situ hybridization study. Neurosci Lett 122:67-70.
Sesack SR, Deutch AY, Roth RH, Bunney BS (1989) 'Topographical organization of the efferent projections of the medial prefrontal cortex in the rat: an anterograde tract-tracing study with Phaseolus vulgaris leucoagglutinin. J Comp Neurol 290:213-242.

Sharp FR, Sagar SM, Hicks K, Lowenstein D, Hisanaga K (1991) c-fos mRNA, Fos, and Fos-related antigen induction by hypertonic saline and stress. J Neurosci 11:2321-2331.

Sharp T, Zetterström T, Ljungberg T, Ungerstedt U (1987) A direct comparison of amphetamine-induced behaviours and regional brain dopamine release in the rat using intracerebral dialysis. Brain Res 401:322-330.

Sheng M, Greenberg ME (1990) The regulation and function of c-fos and other immediate early genes in the nervous system. Neuron 4 : $477-485$.

Sivam SP, Breese GR, Krause JE, Napier TC, Mueller RA, Hong J-S (1987) Neonatal and adult 6-hydroxydopamine-induced lesions differentially alter tachykinin and enkephalin gene expression. J Neurochem 49:1623-1633.

SokoloffP, Giros B, Martres M-P, Bouthenet M-L, Schwartz J-C (1990) Molecular cloning and characterization of a novel dopamine receplor $\left(D_{3}\right)$ as a target for neuroleptics. Nature 347:146-151.

Sukhatame VP, Kartha S, Toback FG, Taub R, Hoover RG, TsaiMorris C-H (1987) A novel early growth response gene rapidly induced by fibroblast, epithelial and lymphocyte mitogens. Oncogene Res 1:343-355.

Sukhatme VP, Cao XM, Chang LM, Tsai-Morris C-H, Stamenkovich D, Ferreira PC, Cohen DR, Edwards SA, Shows TB, Curran T (1988) A zinc finger-encoding gene coregulated with $\mathrm{c}$-fos during growth and differentiation, and after cellular depolarization. Cell 53:37-43.

Sunahara RK, Guan H-C, O'Dowd BF, Seeman P, Laurier LG, Ng G, George SR, Torchia J, Van Tol HHM, Niznik HB (1991) Cloning of the gene for a human dopamine $D_{5}$ receptor with higher affinity for dopamine than $D_{1}$. Nature 350:614-619.

Taylor D, Ho BT (1978) Comparison of the inhibition of monoamine uptake by cocaine methylphenidate and amphetamine. Res Commun Chem Pathol Pharmacol 21:67-75.

Tennyson VM, Barrett RE, Cohen G, Cote L, Heikkila R, Mytilneou $C$ (1972) The developing neostriatum of the rabbit: correlation of fluorescence histochemistry, electron microscopy, endogenous dopamine levels, and $\left[{ }^{3} \mathrm{H}\right]$ dopamine uptake. Brain Res 46:251-285.

Tsai-Morris C-H, Cao X, Sukhatme VP (1988) 5' flanking sequence and genomic structure of $E g r-1$, a murine mitogen inducible zinc finger encoding gene. Nucleic Acids Res 16:8835-8846.

van der Kooy D (1984) Developmental relationships between opiate receptors and dopamine in the formation of caudate-putamen patches. Dev Brain Res 14:300-303.

Van Tol HHM, Bunzow JR, Guan H-C, Sunahara RK, Seeman P, Niznik HB, Civelli O (1991) Cloning of the gene for a human dopamine $\mathrm{D}_{4}$ receptor with high affinity for the antipsychotic clozapine. Nature 350:610-614.

Vickroy TW, Johnson KM (1982) Similar dopamine releasing effects of phencyclidine and non-amphetamine stimulants in striatal slices. J Pharmacol Exp Ther 223:669-674.

Voorn P, Kalsbeek A, Jorritsma-Byham B, Groenewegen HJ (1988) The pre- and postnatal development of the dopaminergic cell groups in the ventral mesencephalon and the dopaminergic innervation of the striatum of the rat. Neuroscience 25:857-888.

Wallace DM, Magnuson DJ, Gray TS (1989) The amygdalo-brainstem pathway: selective innervation of dopaminergic, noradrenergic and adrenergic cells in the rat. Neurosci Lett 97:252-258.

Waters CM, Hancock DC, Evan GI (1990) Identification and characterization of the egr-1 gene product as an inducible, short-lived, nuclear phosphoprotein. Oncogene 5:669-674.

Wisden W, Errington ML, Williams S, Dunnett SB, Waters C, Hitchcock D, Evans G, Bliss TVP, Hunt SP (1990) Differential expression of immediate early genes in the hippocampus and spinal cord. Neuron 4:603-614.

Young ST, Porrino LJ, Iadarola MJ (1991) Cocaine induces striatal c-Fos-immunoreactive proteins via dopaminergic D1 receptors. Proc Natl Acad Sci USA 88:1291-1295.

Zetterström T, Sharp T, Marsden CA, Ungersted U (1983) In vivo mcasurement of dopamine and its metabolites by intracerebral dialysis: changes after $d$-amphetamine. J Neurochem 41:1769-1773. 